\title{
Potential of Fish Pond Sediments Composts as Organic Fertilizers
}

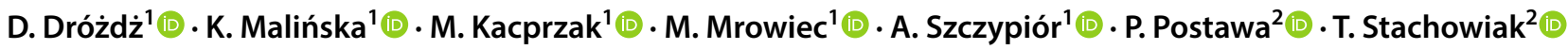

Received: 1 November 2019 / Accepted: 16 April 2020 / Published online: 26 April 2020

(c) The Author(s) 2020

\begin{abstract}
Increased fish pond production is associated with the generation of various waste including fish pond sediments. Fish pond sediments could be a valuable source of nutrients for growing plants, however they require further processing in order to be applied to soil. Composting is considered one of the methods for processing fish pond sediments. The aim of this work was to investigate the potential of organic fish pond sediments to be managed through laboratory composting with selected waste materials and evaluate the fertilizing potential of the obtained compost. The scope included: (1) analysis of organic fish pond sediments, (2) laboratory composting of organic fish pond sediments with wheat straw and green grass, (3) analysis of the obtained composts, (4) preparation of growing media with selected additives, (5) analysis of the properties of the prepared growing media and (6) analysis of the effect of the investigated growing media on the growth of Phaseolus vulgaris L. in pot experiments. The addition of cardboard waste and woodchips derived biochar to the obtained compost improved significantly the growth of the roots of Cardamine L. Also, the content of carbon and nitrogen in the compost mixtures increased. The addition of M1 (compost from organic fish pond sediments and 1\% of biochar) to the soil had a significant impact on the growth of white beans.
\end{abstract}

\section{Graphic Abstract}

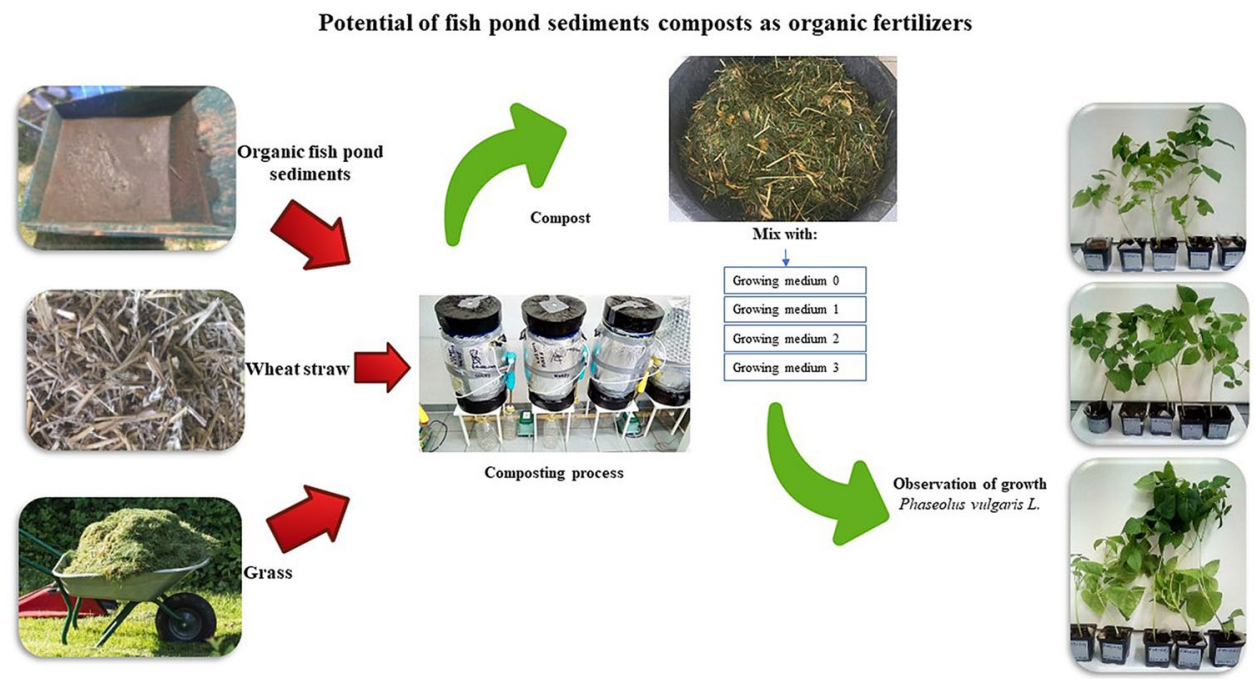

Keywords Organic fish pond sediments · Organic aquaculture · Organic fertilizers · Organic waste · Composting · Fertilization

D. Dróżdż

d.drozdz@is.pcz.pl

Extended author information available on the last page of the article 


\section{Statement of Novelty}

Intensive organic aquaculture can generate significant amounts of waste, in particular such as fish pond sediments removed periodically from fish tanks or ponds. This type of waste material can be a source of many nutrients with a fertilizing potential. The literature provides numerous examples of studies on management of fish pond sediments coming from conventional aquaculture systems. However, there is little known about physical and chemical properties and management practices for fish pond sediments from organic aquaculture. The presented study on fish pond sediments from organic aquaculture of trout can contribute to the advancement of the state of the art by providing information on the physical and chemical properties of fish pond sediments. We hypothesized that fish pond sediments from organic aquaculture can be managed through composting as an alternative to storing or direct landfilling of fish pond sediments. Composting can be applied as a method for managing fish pond sediments on site, i.e. on an organic fish farm, with other typically available waste materials such as straw or grass. In addition, fertilization potential of a compost obtained from fish pond sediments for plant growth was analyzed. The overall outcome of the presented study will fill in the gap in the literature on properties of fish pond sediments from organic aquaculture and allow better understanding of how this type of waste could be handled and further used for growing plants. In addition, prior to this study we performed a review of the available literature to learn about properties of fish pond sediments from organic aquaculture and what are the methods for handling and managing of this type of waste. This was well received by the reviewers and published in International Agrophysics. Article title Fish pond sediments from aquaculture production-current practices and potentials for nutrient recovery, https://doi. org/10.31545/intagr/116394. The issue on managing fish pond sediments from organic aquaculture is being investigated in the frame of $\mathrm{H} 2020$ project titled: Phasing out contentious input from organic agriculture (2018-2022).

\section{Introduction}

According to the available data, there was a significant increase in organic production of fish such as trout and salmon observed in Europe during the period of 2012-2015 (by $100 \%$ and 24\%, respectively) [1]. In Poland, the fish production continues to grow every year. The conventional production of fish increased from 45,000 tonnes in 2010 to 51,000 tonnes in 2016 [2, 3].
The organic production of fish in Poland can vary, and for example, in 2015 it was estimated at 19,000 tons of fish [4]. Production of fish in organic systems differs significantly from conventional systems. Conventional fish farms are characterized by the dense arrangement of fish in the ponds or tanks, for example, 1000 fish per ha whereas for organic it is about $600-750$ pcs per ha. Organic fish is fed with organic certified cereals. The bottoms of the ponds are periodically limed, or iron sulphate is added whereas in conventional ponds no preventive treatments are carried out [5]. In the case of conventional aquaculture, the quantities of generated fish pond sediments can vary from 148 to $338 \mathrm{~kg}$ whereas in organic aquaculture it is in the range of $8-11 \mathrm{~kg}$ per ton of fish $[6,7]$. Preventive treatments, organic feeding, certified feed, smaller amount of fish also have an impact on the quality of fish pond sediments. What is more, the oxygen content is important for proper functioning of the ponds. In the case of conventional aquaculture, the oxygen depletion occurs faster due to excessive bottom sediment. In organic farms, however, the oxygen concentration is maintained at the same level throughout the year [8]. Small amounts of organic sediments are not as dangerous as the excessive amount of bottom sediments from conventional breeding, because they also do not generate significant quantities of toxic gases like ammonia [9]. The risk associated with bottom sediments from conventional aquaculture is also associated with the means used in the ponds to eliminate unwanted organisms. In extreme cases, contaminants such as insecticides, pesticides, heavy metals, among others arsenic, mercury, cadmium, chromium, beryllium and aluminum, cyanide can pose a threat to people and the water organisms which we eat. If accumulated in a significant amount in a human body, they could be carcinogenic [10].

Organic bottom sediments are removed manually from the water reservoir. Depending on the volume of the tank, this process is repeated 2-3 times a year. Then, the sediments can be stored or left to dry in the air in designated areas on fish farms. The common practice is to use fish pond sediments for soil applications (personal communications). However, sediments from conventional fish farms are formed in much larger quantities. There are many applications described in the literature, including storage. In addition, conventional fish pond sediments are subjected to biological processes and used for fertilizing purposes [11]. Fertilizers from fish pond sediments have found application in the cultivation of such plants as Lolium perenne, Lolium multiflorum, Lolium westerwoldicum, fodder grass. Fish pond sediments can be also applied as a material for building quays, road embankments. Also, fish pond sediments are used as one of the ingredients in feed for animals. Fish pond sediments can be also used for composting and vermicomposting to obtain composts. Small amounts could be used as an additive in 
energy recovery systems (e.g. biogas additive), and as a growth medium for algae [4, 11-18].

The literature provides more examples of using fish pond sediments from conventional fish farms than from organic ones. Properties of fish ponds sediments characterized by $\mathrm{pH}$ 6-7.7, nitrogen $1.08-7.03 \mathrm{~g}^{*} \mathrm{~kg}^{-1}$, carbon $18.3-92.3 \mathrm{~g}^{*} \mathrm{~kg}^{-1}$, potassium $0.62-2.25 \mathrm{~g}^{*} \mathrm{~kg}^{-1}$ and phosphorus $0.22-2.07 \mathrm{~g}^{*} \mathrm{~kg}^{-1}$ [11]. In fish pond sediments, there are also bacteria with probiotic properties such as Bacillus, Lactobacillus coryniformis, Lactobacillus brevis, Lactobacillus farciminis, and Lactobacillus collinoides [19]. But in both aquaculture systems, bottom sediments are generated and need to be handled and managed, preferably on site. One of the methods for managing organic fish pond sediments on site could be composting with selected waste materials available already on a fish farm such as straw or grass.

The overall goal of this study was to investigate the potential of organic fish pond sediments as a source of valuable nutrients for the production of composts and analyze the impact on plant growth. The scope of this work included: (1) the analysis of the properties of organic fish pond sediments sampled from an organic trout farm (Poland), (2) composting of organic fish pond sediments mixed with selected waste materials (wheat straw and grass), (3) analysis of selected properties of the obtained compost, (4) preparation of compost mixtures with selected additives (biochar and cardboard waste) and the analysis of selected properties, (5) preparation of growing media by mixing soil susceptible to water loss with the compost mixtures and the analysis of selected properties, (6) analysis of properties of the prepared growing media after reaching the equilibrium and (7) the analysis of the impact of compost mixtures on the growth and yield of Phaseolus vulgaris $L$.

\section{Materials and Methods}

This study was conducted at the laboratory of the Department of Environmental Engineering, Częstochowa University of Technology, Częstochowa, Poland.

\section{Substrates Used in this Study}

Organic fish pond sediments (FPS) were used as a substrate for composting, FPS were collected from the organic fish farm in Złoty Potok (Poland) with primary production of rainbow trout (Oncorhynchus mykiss). Organic fish pond sediments were mixed with readily available bulking agents such as wheat straw (WS) and freshly cut grass (FG) in the following ratio: (FPS:FG:WS) 1:0.78:0.03 wet weight, i.e. $9 \mathrm{~kg}$ of FPS mixed with $7 \mathrm{~kg}$ of FG and $0.3 \mathrm{~kg}$ of WS (1:1.43:0.09 dry weight). These proportions allowed fulfilling the requirements for proper composting.
Other substrates used in this study included biochar and cardboard waste. Biochar was produced from woodchips and purchased from a commercial pyrolysis plant in Poland. The woodchips derived biochar demonstrated nitrogen content of $0.83 \%$ (TN), total organic carbon of $75.3 \%$ (TOC), ratio $\mathrm{C} / \mathrm{N}$ of $231, \mathrm{pH}$ of 7.4, conductivity $183 \mu \mathrm{S}$ (EC), ash content $3.95 \%$, moisture content $4.26 \%$ (MC). The content of chemical elements was as follows: total P (TP) $0.054 \%$ (TP), $\mathrm{Mg}$ of $680 \mathrm{mg} \mathrm{kg}^{-1}, \mathrm{Hg}$ of $0.011 \mathrm{mg} \mathrm{kg}^{-1}, \mathrm{Zn}$ of $75.4 \mathrm{mg} \mathrm{kg}^{-1}$, $\mathrm{Cd}$ of $0.368 \mathrm{mg} \mathrm{kg}^{-1}, \mathrm{~Pb}$ of $1.65 \mathrm{mg} \mathrm{kg}^{-1}$ [20]. Cardboard waste came from recycled cartons and egg packaging. The total content of organic matter (OM) was $89.2 \%$, total nitrogen-0.1\% (N), total organic carbon-43.5 (TOC), $\mathrm{pH} 8.7$, and $\mathrm{C} / \mathrm{N}$ ratio $386[21,22]$.

The soil used for this study was sampled from the agricultural fields in the vicinity of Częstochowa (Poland). According to the Drought Monitoring System for Poland (ADMS) provided by the Institute of Soil Science and Plant Cultivation-State Research Institute (IUNG-PIB) on behalf of the Ministry of Agriculture and Rural Development, this agricultural fields were classified as soils which are very susceptible to drought (according to the Available water content for the plant-AWC ratio) and consisted mainly of loose and weakly loamy sands [23]. Loss of large amounts of water causes the problem with the growth of plants on these soils [24]. What is more, this type of soil was selected for this study as the most typical for Poland.

\section{Laboratory Composting Reactor}

The $60 \mathrm{~L}$ laboratory composting reactor was equipped with the force aeration system, flow controllers, measurement sensors for temperature, and condensate and leachate collection sets (Fig. 1) [21, 25, 26]. The system of aeration and drainage of leachates from the reactor prevents from the formation of anaerobic zones in the composting reactor (which

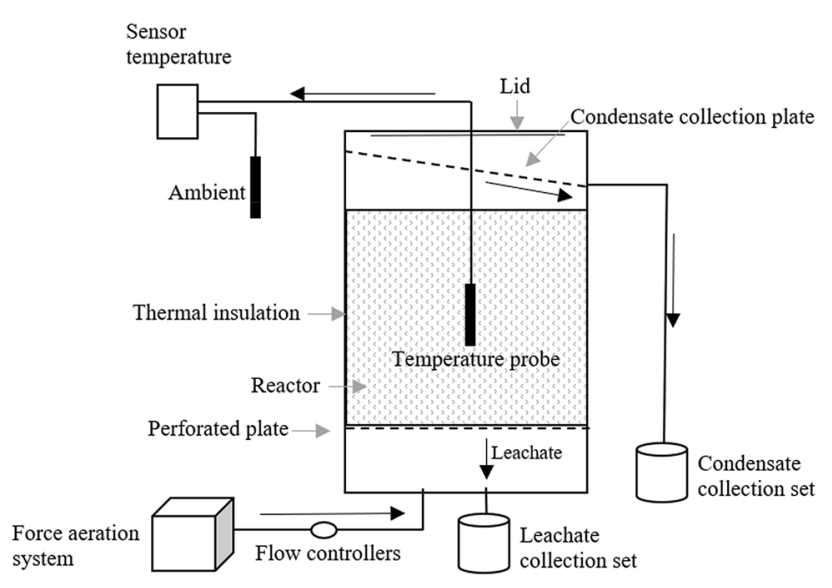

Fig. 1 A laboratory composting reactor 
can cause uncontrolled decomposition of organic matter and the formation of unpleasant odors) [24, 27].

\section{Methods}

\section{Laboratory Composting}

The initial composting mixture was prepared from fresh organic fish pond sediments that were mixed with wheat straw and wet grass (from mowing the lawns). Composting of this mixture was carried out for 28 days. The process was controlled by daily temperature measurement with a temperature probe. The average air flow rate was $35 \mathrm{l} / \mathrm{h}$ (at the start of the experiment it was set at $50 \mathrm{l} / \mathrm{h}$, and with time it was changed to $35 \mathrm{l} / \mathrm{h}$. The composting mixture was manually mixed after 2 weeks of composting. Solid samples were collected during and after the completion of composting. All solid samples were tested for moisture content (MC), organic matter (OM), total organic carbon (TOC), Kjeldahl nitrogen $(\mathrm{TN})$ and $\mathrm{pH}$.

\section{Preparation of the Compost Mixtures and Growing Media}

The obtained compost from organic fish pond sediments (CFPS) was air-dried, amended with selected materials, i.e. cardboard waste (C) and woodchips derived biochar (B), and then ground in a laboratory grinder (Testchem PZS01). The following compost mixtures were obtained: (1) Mixture 1 (M1) - the compost amended with cardboard waste, (2) Mixture 2 (M2) - the compost amended with woodchips derived biochar, and (3) Mixture 3 (M3) - the compost amended with cardboard waste and woodchips derived biochar. Table 1 shows the weight ratio of the obtained compost from fish pond sediments (CFPS) amended with cardboard waste (C) and woodchips derived biochar (B).

The compost mixtures M1, M2 and M3 were then mixed with the investigated soil to obtain growing media used for the pot experiment. The sampled soil demonstrated susceptibility to drought and was classified as the soil category I (loose sand, loose dusty, poorly loamy) [28]. The soil was sieved through a sieve with a mesh size of $1.5-2 \mathrm{~mm}$. Then, the air-dry soil was mixed with the produced compost mixtures, i.e. the soil + the obtained compost, the soil + the
Table 2 Preparation of growing media for the pot experiment

\begin{tabular}{|c|c|c|c|c|}
\hline \multirow[t]{3}{*}{ Ratios } & \multicolumn{4}{|l|}{ Treatments } \\
\hline & $\begin{array}{l}\text { Growing } \\
\text { medium (GM } \\
0)\end{array}$ & $\begin{array}{l}\text { Growing } \\
\text { medium } 1 \\
\text { (GM 1) }\end{array}$ & $\begin{array}{l}\text { Growing } \\
\text { medium } 2 \\
(\text { GM 2) }\end{array}$ & $\begin{array}{l}\text { Growing } \\
\text { medium } 3 \\
\text { (GM 3) }\end{array}$ \\
\hline & (S:Compost) & (S:M1) & (S:M2) & (S:M3) \\
\hline Dry weight & $1: 0.03$ & $1: 0.03$ & $1: 0.03$ & $1: 0.03$ \\
\hline Wet weight & 1:0.07 & $1: 0.07$ & 1:0.07 & 1:0.07 \\
\hline
\end{tabular}

compost mixture (M1), the soil + the compost mixture 2, and the soil + the compost mixture 3 . Table 2 shows the weight ratio of the compost mixtures and the soil. The ratio of compost added to the soil was adjusted in order not to exceed the nitrogen content per $1 \mathrm{~kg}$ of soil [29]. To assure geochemical equilibrium, the growing media $0,1,2,3$ were left for 5 weeks in a dry place at $20-24{ }^{\circ} \mathrm{C}[30]$ and watered once a week to maintain proper moisture content [31].

After reaching the equilibrium the growing media 0,1 , 2 and 3 were again tested for water content (MC), organic matter (OM), phosphorus, Kjeldahl nitrogen, carbon (TOC) and $\mathrm{pH}$.

\section{Physical and Chemical Analysis}

The substrate, mixtures and compost were tested for moisture content $(\mathrm{MC})$, organic matter $(\mathrm{OM})$, total nitrogen $(\mathrm{TN})$, phosphorus (P), total organic carbon (TOC), $\mathrm{pH}$ and selected elements were performed. MC was determined by drying the samples at $105^{\circ} \mathrm{C}$ to constant weight. The content of organic matter $(\mathrm{OM})$ was determined by the loss on ignition of the dried mass in a muffle furnace at $550^{\circ} \mathrm{C}$ for $3 \mathrm{~h}$. Total nitrogen (TN) was analyzed by the Kjeldahl method. The content of phosphorus was determined by the spectrophotometric method (Hach Lange DR 5000) with ammonium molybdate [32]. The content of carbon in solid samples was analyzed with the organic carbon analyzer (TOC) (Carbon Analyzer Multi N/C 2100, Analytikjena) at high temperature $\left(1200{ }^{\circ} \mathrm{C}\right)$ oxidation in the stream synthetic air [33]. The $\mathrm{pH}$ was measured with a laboratory $\mathrm{pH}$ multifunction device/conductometer (Elmetron CPC-505). The analysis of trace amounts of chemical elements by means of inductively

Table 1 Compost from fish pond sediments amended with selected materials

\begin{tabular}{llll}
\hline Ratios of mixtures & \multicolumn{2}{l}{ Compost mixtures } & \\
\cline { 2 - 4 } & $\begin{array}{l}\text { Compost amended with card- } \\
\text { board waste-Mixture 1 (M1) } \\
\text { (CFPS:C) }\end{array}$ & $\begin{array}{l}\text { Compost amended with woodchips } \\
\text { derived biochar-Mixture 2 (M2) } \\
\text { (CFPS:B) }\end{array}$ & $\begin{array}{l}\text { Compost amended with cardboard waste and } \\
\text { woodchips derived biochar—Mixture 3 (M3) } \\
\text { (CFPS:C:B) }\end{array}$ \\
\hline Dry weight & $1: 0.09$ & $1: 0.02$ & $1: 0.09: 0.02$ \\
Wet weight & $1: 0.06$ & $1: 0.01$ & $1: 0.06: 0.01$ \\
\hline
\end{tabular}


coupled plasma mass spectrometry (ICP-OES MS) was also carried out. All samples were tested in 3 replications.

\section{Phytotoxicity Test}

The phytotoxicity test was performed for the obtained compost, the investigated soil and the growing media 1,2, 3 . This test was performed using the seed germination bioassay test according to Mitelut (2011) [34] with cress seeds (Cardamine L.). The test was carried out in 4 replications for each extract concentration, i.e.: $0 \%, 25 \%, 50 \%, 75 \%, 100 \%$. The extracts and seeds on Petri dishes were incubated at $25{ }^{\circ} \mathrm{C}$ for $72 \mathrm{~h}$. After this time, the sprouted seeds were counted, and roots length was measured. The germination index of the seeds was calculated from the following formula (Eq. 1):

$\left(\mathrm{G}_{\mathrm{i}}\right)=\left(\left(\mathrm{G} / \mathrm{G}_{0}\right) *\left(\mathrm{~L} / \mathrm{L}_{0}\right)\right)-100$, units $[\%]$.

where; $\mathrm{G}$, the number of seeds that germinated in the sample analyzed, L, root length in the analyzed sample, units [mm], $\mathrm{G}_{\mathrm{O}}$, the number of seeds that germinated in a $0 \%$ control sample, $\mathrm{L}_{0}$, root length in a $0 \%$ control sample, units [mm] $[34,35]$.

\section{Pot Experiment}

In order to evaluate the effect of the compost mixtures on soil properties and the plant growth and yield the pot experiment was performed in the laboratory scale. The investigated growing media were transferred to the pots. Each pot contained $260 \mathrm{~g}$ of the growing medium, i.e. 0, 1, 2 and 3 . Also, each pot was equipped with a water permeable material at the bottom which counteracted the soil loss from the pot. Each treatment was performed in 5 replications. White kidney bean seeds (Phaseolus vulgaris L.) were placed in the pots and kept in the laboratory with natural sunlight. White kidney bean was selected as a leguminous plant quickly germinates, shows the ability to bind nitrogen, and is readily available $[36,37]$. Also, it has low requirements for nitrogen. After 3 months of the pot experiment the plant biomass was removed from the soil, weighed, measured and air-dried.

\section{Results and Discussion}

\section{Characteristics of Substrates, Composting Mixtures, Compost and Composting Mixtures, and Growing Media}

\section{Characteristics of Substrates for Composting}

Table 3 shows the selected properties of the substrates used for composting. Fresh bottom sediments from the organic fish farm in Złoty Potok (Poland) demonstrated high water content and alkaline $\mathrm{pH}$. The $\mathrm{P}_{2} \mathrm{O}_{5}$ content was at the level of $13.88 \mathrm{mg} \mathrm{g}^{-1}$. The determination was made on the basis of Egner-Riehm extraction The phosphorus content in the fish pond sediments ranged from 10.1 to 15.0 (medium) mg. $\mathrm{P}_{2} \mathrm{O}_{5}$ per $100 \mathrm{~g}$ soil [38]. Fresh grass and wheat straw showed similar content of total organic carbon.

Wheat straw showed the highest $\mathrm{C} / \mathrm{N}$ ratio which is typical for this type of a bulking agent. The use of straw allowed achieving the compost porosity and adequate airflow in the composting reactor [21]. The addition of fresh grass and wheat straw increased the amount of organic carbon in the composting mixture. Carbon is necessary for microorganisms that need it to carry out many chemical processes in the composter. Microorganisms consume about $15-20 \%$ of carbon during the entire composting process [39]. As for the organic fish pond sediments the content of organic matter (OM) and total organic carbon (TOC) was the lowest. The low OM and TOC content may depend on the type of system in which the fish was bred. Three types of breeding can be distinguished, i.e. Recirculating aquaculture system (RAS), Flow-through system (FTS), Pond system. The farm from which fish pond sediments were collected used the FTS system. This was related to the fact that the flow through the pond, which was fed with water from the river, caused leaching/transfer of organic substances along with its current, out of the pond [11].

\section{Temperature During the Process of Composting}

The organic fish pond sediments with fresh grass and wheat straw were composted for 28 days. The measurement of

Table 3 Selected properties of the materials used in this study

\begin{tabular}{|c|c|c|c|c|c|c|}
\hline Substrate & $\mathrm{pH}$ & Moisture content (MC) & Organic matter $(\mathrm{OM})$ & Total nitrogen & $\begin{array}{l}\text { Total organic } \\
\text { carbon (TOC) }\end{array}$ & Ratio $\mathrm{C} / \mathrm{N}$ \\
\hline Units & - & $\%$ & $\%$ & $\%$ & $\%$ & - \\
\hline Fish pond sediments & 7.61 & $63.48 \pm 1.72$ & $30.38 \pm 2.13$ & $0.41 \pm 0.18$ & $10.19 \pm 0.45$ & 25 \\
\hline Fresh grass & 6.31 & $64.36 \pm 1.37$ & $92.32 \pm 0.80$ & $1.46 \pm 0.12$ & $36.29 \pm 0.08$ & 25 \\
\hline Wheat straw & 6.60 & $8.25 \pm 2.12$ & $95.80 \pm 0.61$ & $0.45 \pm 0.08$ & $36.84 \pm 0.43$ & 82 \\
\hline
\end{tabular}


temperature inside the reactor and ambient was performed on daily basis (Fig. 2). Temperature during composting is the key parameter which shows the dynamics of the process. It indicates when the active phase of composting terminated, and the process is completed [21].

The temperature increased in the initial phase (form day 0 do day 4) up to $52{ }^{\circ} \mathrm{C}$. The composting mixture from the active phase began to stabilize on the day 12 . Within the next 14 days the temperature dropped to $22^{\circ} \mathrm{C}$, close to ambient which indicated that the active phase was completed. This is typical for the composting $[14,20]$.

\section{Properties of the Compost from Fish Pond Sediments and the Compost Mixtures M1, M2, M3}

The obtained compost and compost mixtures M1, M2, M3 were analyzed for selected physical and chemical properties (Table 4). The water content increased after 2 weeks of composting-which is typical for experiments in laboratory composting reactors and decreased at the end of the process. The $\mathrm{C} / \mathrm{N}$ ratio dropped from 26 to 12 in the obtained compost. The $\mathrm{C} / \mathrm{N}$ ratio of $15: 1$ is typical for stabilized compost [40]. This is also related to the decrease in the carbon content in the obtained compost. In the obtained compost and the compost mixtures M1, M2 and M3, the total nitrogen content and $\mathrm{pH}$ increased. This was related to the loss of organic matter and the processes occurring in the composter [41].

The $\mathrm{pH}$ values increased during composting of organic fish pond sediments. The increase in $\mathrm{pH}$ in the initial stages of composting is associated with the release of ammonia which in the phase of ammonification and organic nitrogen mineralization is necessary during microbial activity. When the compost matures its $\mathrm{pH}$ value decreases and remains at about 7.5. The drop in $\mathrm{pH}$, after about 25-29 days, can be caused by the oxidation of ammonium nitrogen, the release of $\mathrm{H}^{+}$as a result of nitrification. The release of a large amount of $\mathrm{CO}_{2}$ and the production of organic and inorganic acids in the composting process, also reduces the $\mathrm{pH}$ [39]. The $\mathrm{pH}$ of the compost obtained in the experiment was alkaline. This $\mathrm{pH}$ is suitable for the growth of most plants [17]. The phosphorus content was high, classified as the Class I (Evaluation of phosphorus and potassium contents in mineral soils, based on Egner-Riehm extraction).

\section{Properties of the Growing Media 1, 2, 3}

After the 5-week period necessary for reaching the geochemical equilibrium, the prepared growing media were tested for selected physical and chemical properties (Table 5).

After 5 weeks some of the physical and chemical properties of the growing media changed due to the interactions
Fig. 2 Temperature during the 28-day composting

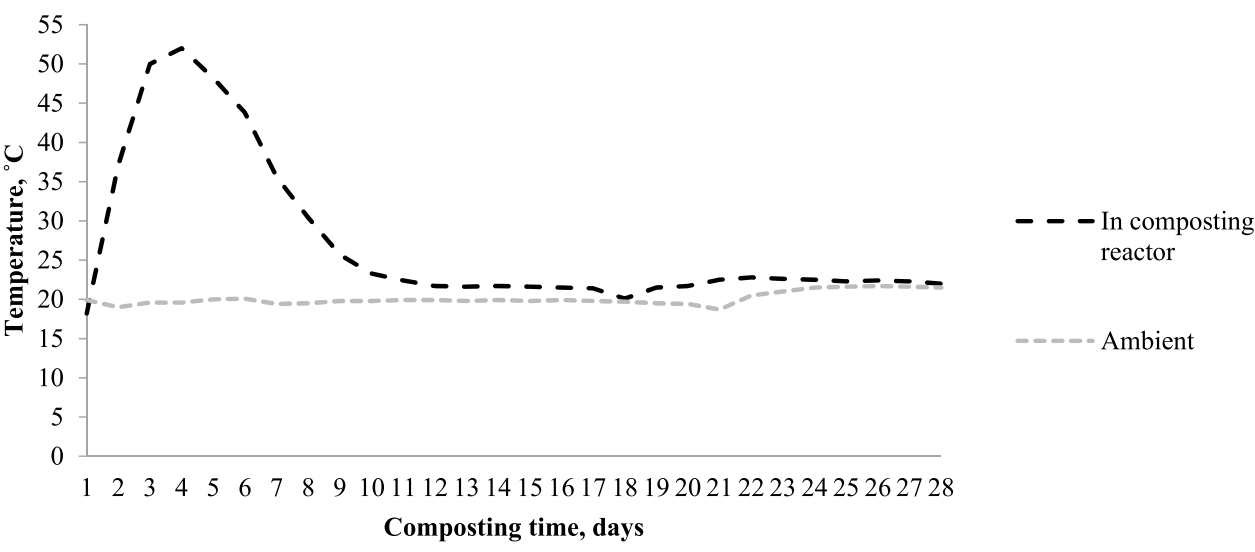

Table 4 Properties of the obtained compost from fish pond sediments and amended with selected materials

\begin{tabular}{lcllllll}
\hline Parameters & $\mathrm{pH}$ & Moisture content (MC) & Organic matter (OM) & $\begin{array}{l}\text { Total organic } \\
\text { carbon (TOC) }\end{array}$ & Total nitrogen $(\mathrm{TN})$ & $\mathrm{P}_{2} \mathrm{O}_{5}$ & $\mathrm{C} / \mathrm{N}$ \\
\hline Units & - & $\%$ & $\%$ & $\%$ & $\%$ & $\mathrm{mg} \mathrm{g}^{-1}$ & - \\
Start of composting & 7.06 & $72.25 \pm 1.41$ & $51.34 \pm 2.84$ & $19.56 \pm 0.06$ & $0.76 \pm 0.28$ & $1.37 \pm 0.01$ & 26 \\
Composting after 2 weeks & 8.21 & $75.39 \pm 1.00$ & $37.43 \pm 3.43$ & $18.36 \pm 0.22$ & $1.32 \pm 0.20$ & $1.20 \pm 0.01$ & 14 \\
End of composting & 8.54 & $71.64 \pm 2.55$ & $32.56 \pm 3.58$ & $17.42 \pm 0.49$ & $1.43 \pm 0.16$ & $1.47 \pm 0.01$ & 12 \\
Compost mixtures (M1) & 8.55 & $70.35 \pm 1.52$ & $41.78 \pm 3.19$ & $19.74 \pm 0.71$ & $1.26 \pm 0.12$ & $1.14 \pm 0.01$ & 16 \\
Compost mixtures (M2) & 8.64 & $72.73 \pm 0.87$ & $39.31 \pm 0.88$ & $18.37 \pm 0.44$ & $1.23 \pm 0.20$ & $1.26 \pm 0.01$ & 15 \\
Compost mixtures (M3) & 8.53 & $71.21 \pm 1.10$ & $40.70 \pm 0.69$ & $19.66 \pm 0.23$ & $1.16 \pm 0.18$ & $1.15 \pm 0.01$ & 17 \\
\hline
\end{tabular}


with added composts and water. Those changes in soil properties resulted from stabilization, microorganism's activity, leaching due to water supply and evaporation, etc. [30, 39, 40, 42, 43].

All the prepared growing media $(0,1,2,3)$ demonstrated higher contents of organic matter, total organic carbon and phosphorous, and $\mathrm{pH}$ than the control (soil). However, no significant changes between these growing media were observed.

\section{Phytotoxicity Test with Cardamine $L$.}

Phytotoxicity test was performed for all the investigated growing media: control (soil), growing media $0,1,2$ and 3 before (week 0 ) and after the completion of 5-week period for reaching the geochemical equilibrium. After 3 days of incubation of cress seeds at $25{ }^{\circ} \mathrm{C}$, the roots of the plant were measured. The figure (Fig. 3) shows the distribution of root length in millimeters, using different concentrations of extracts.

The roots length ranged from 35 to $42 \mathrm{~mm}$. The roots observed in the growing medium 2 and 3 at the concentration of $50 \%$, demonstrated the longest roots which was $42 \mathrm{~mm}$. The figure below (Fig. 4) demonstrates the results that were calculated from the seeds germination index.

The extracts from the growing media 1,2 and 3 showed a similar effect on the seed germination. $G_{i}$ was significantly higher than in the case of the soil (Control) and the growing media 0 (soil mixed with the obtained compost). Phytotoxicity test was performed after 5 -week period for all the

Table 5 Selected properties of the growing media after reaching the geochemical equilibrium

\begin{tabular}{lcllllll}
\hline Parameters & $\mathrm{pH}$ & Moisture content (MC) & Organic matter (OM) & $\begin{array}{l}\text { Total organic } \\
\text { carbon (TOC) }\end{array}$ & Total nitrogen $(\mathrm{TN})$ & $\mathrm{P}_{2} \mathrm{O}_{5}$ & $\mathrm{C} / \mathrm{N}$ \\
\hline Units & - & $\%$ & $\%$ & $\%$ & $\%$ & $\mathrm{mg} \mathrm{g}^{-1}$ & - \\
Control (Soil) & 7.65 & $9.35 \pm 0.21$ & $3.15 \pm 0.49$ & $2.37 \pm 0.13$ & $0.12 \pm 0.00$ & $0.23 \pm 0.02$ & 20 \\
Growing medium 0 & 7.95 & $17.20 \pm 0.36$ & $5.12 \pm 0.11$ & $3.44 \pm 0.14$ & $0.22 \pm 0.01$ & $0.49 \pm 0.01$ & 16 \\
Growing medium 1 & 8.04 & $11.26 \pm 0.45$ & $5.08 \pm 0.14$ & $3.48 \pm 0.05$ & $0.21 \pm 0.00$ & $0.53 \pm 0.01$ & 17 \\
Growing medium 2 & 7.93 & $12.09 \pm 0.36$ & $5.22 \pm 0.63$ & $4.78 \pm 0.08$ & $0.21 \pm 0.00$ & $0.50 \pm 0.03$ & 23 \\
Growing medium 3 & 8.13 & $16.21 \pm 0.29$ & $4.85 \pm 0.36$ & $3.20 \pm 0.02$ & $0.21 \pm 0.00$ & $0.48 \pm 0.03$ & 15 \\
\hline
\end{tabular}

Fig. 3 The length (L) of cress roots (Cardamine L.) (week 0)

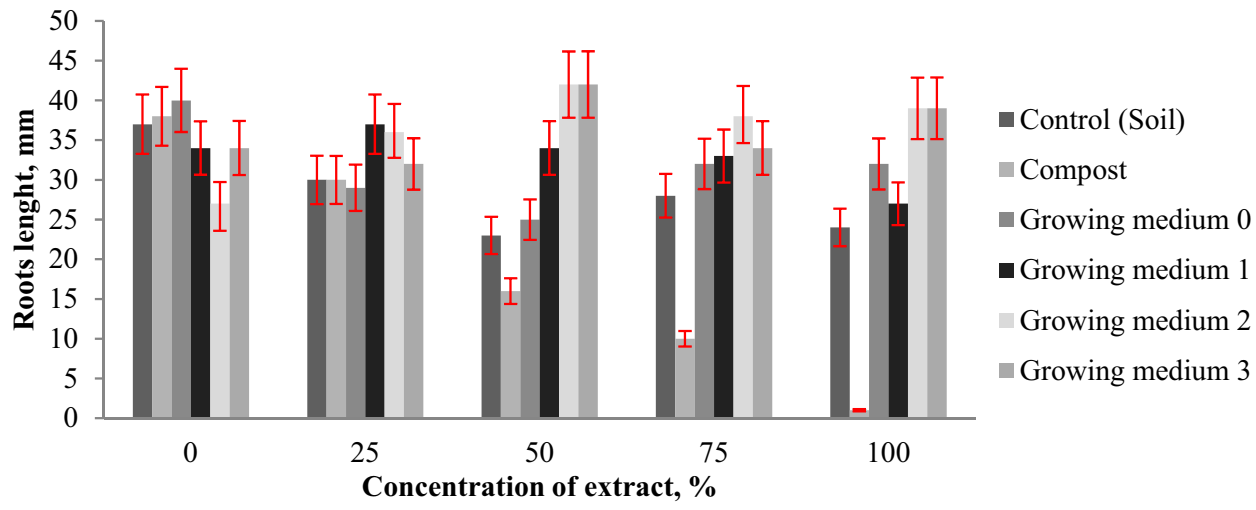

Fig. 4 Germination index $\left(\mathrm{G}_{\mathrm{i}}\right)$ of cress seeds (Cardamine L.) (week 0)

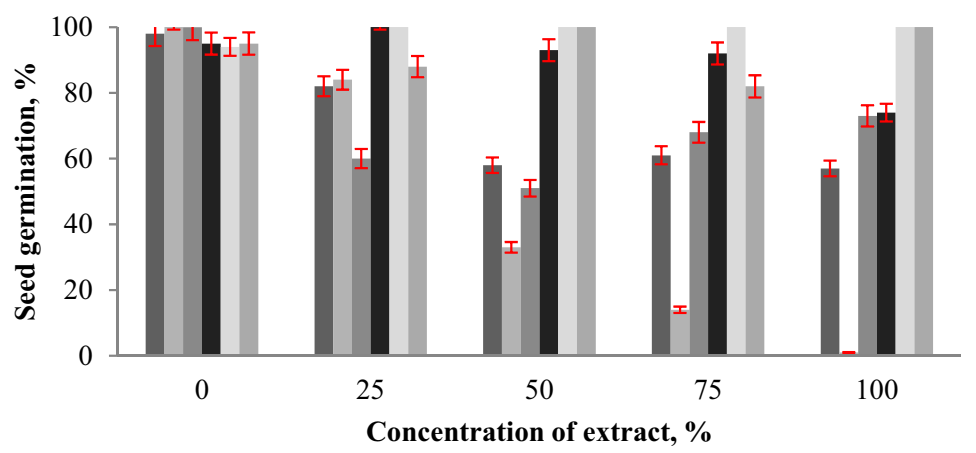

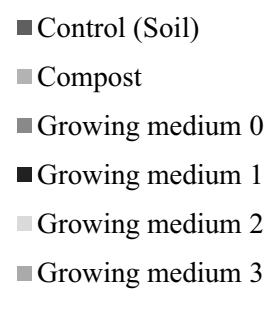

- Control (Soil)

mpos

Growing medium 0

- Growing medium 1

Growing medium 3 
investigated growing media. The results are shown in Figs. 5 and 6.

Comparing 0 and 5-week, the decrease in the length of the roots was observed. None of the results was higher than $40 \mathrm{~mm}$ after 5-week period of geochemical equilibrium whereas the samples taken after 5 weeks of geochemical equilibrium had similar results than at week 0 . The reduction in length and germination could result from lower contents in carbon and phosphorus.

\section{Growth of Phaseolus vulgaris $L$.}

Table 6 presents the results from the pot experiments, i.e. growth and yield of white kidney bean, after 2, 4 and 12 weeks.

Significant plant growth was observed in the pots with the growing media 2 and 3 . The plants had the longest stems and a significant amount of leaves. Table 7 presents the summary for the pot experiment measurements. It was observed that for 5 replicates, all seeds germinated only in the growing medium 2. They also had the longest stems.

After completion of the pot experiment the investigated growing media were subjected to the final physicochemical analysis. The results are presented in Table 8 .

The final results of the physicochemical analysis did not differ significantly from the results obtained after the 5-week geochemical equilibrium. However, the $\mathrm{C} / \mathrm{N}$ ratio in the growing medium 3 increased from 15 to 20 . The remaining growing media also showed a similar $\mathrm{C} / \mathrm{N}$ which was around 20. This could be due to the presence of biochar which could have an impact on $\mathrm{C} / \mathrm{N}$ [44].

The contents of the trace elements in all investigated substrates, the composting mixture, the obtained compost, the compost amended with selected materials as well as the prepared growing media are presented in Table 9. The obtained results were compared with the current legal standards regarding the content of heavy metals in fertilizers.

According to the Ordinance of the Minister of Agriculture and Rural Development of June 18, 2008 on the
Fig. 5 The length (L) of cress roots after the 5 -week period for reaching the geochemical equilibrium

Fig. 6 Germination index (Gi) for cress after the 5-week period for reaching the geochemical equilibrium
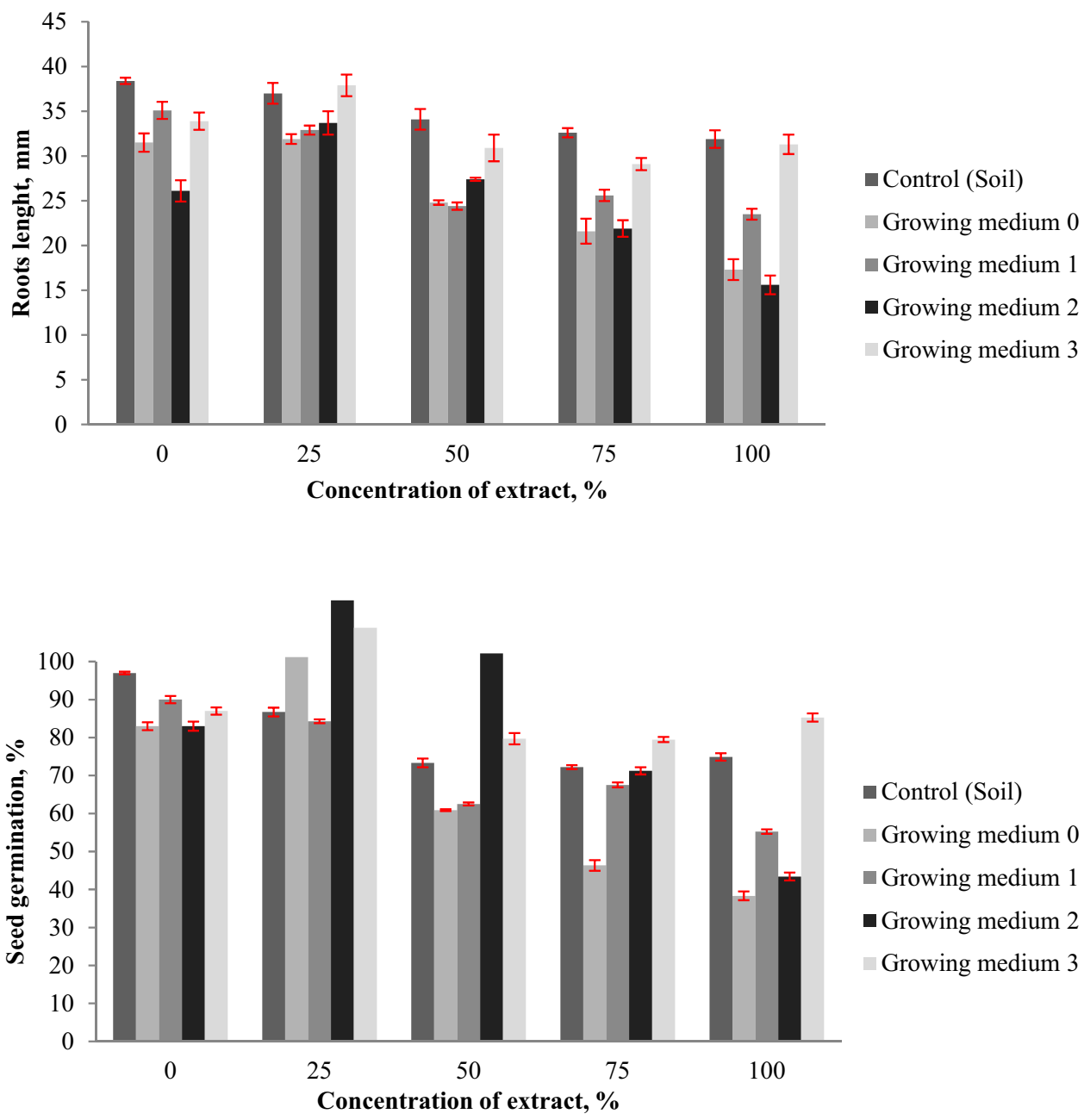

Fig. 6. Germination index (Gi) for cress after the 5-week period for reaching the geochemical equilibrium. 
Table 6 Growth and yield of Phaseolus vulgaris $L$

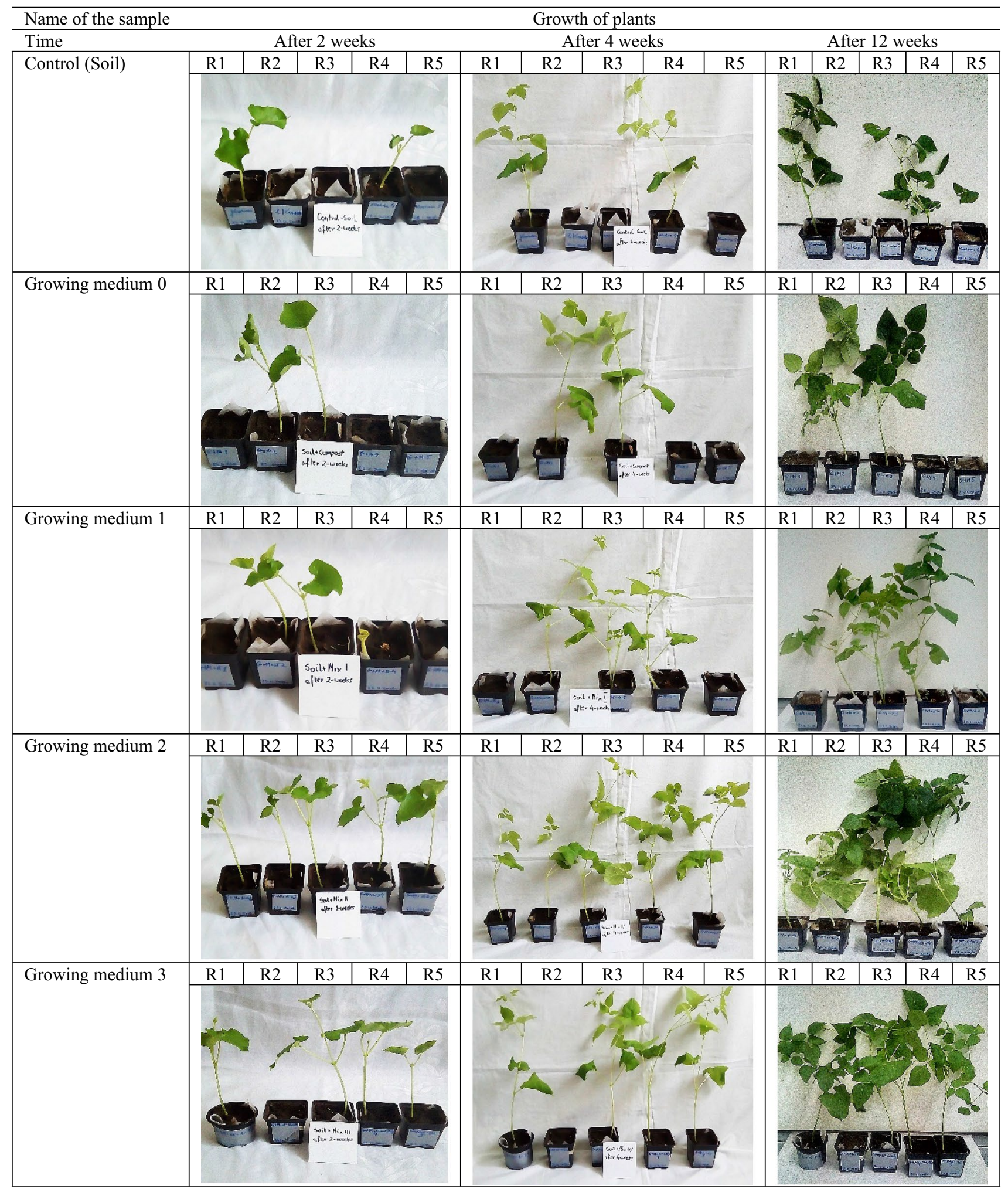

*R1,2,3,4,5 - number of replications. 
Table 7 Selected parameters for plant growth (Phaseolus vulgaris L.) during the pot experiment

\begin{tabular}{|c|c|c|c|c|c|}
\hline \multirow[b]{2}{*}{ Units } & \multirow{2}{*}{$\begin{array}{l}\text { The length of the root } \\
\mathrm{mm}\end{array}$} & \multirow{2}{*}{$\begin{array}{l}\text { Length of the stem } \\
\mathrm{mm}\end{array}$} & \multicolumn{2}{|l|}{ Plant weight } & \multirow{2}{*}{$\begin{array}{l}\text { Number of } \\
\text { germinated } \\
\text { seeds } \\
-\end{array}$} \\
\hline & & & g, wet weight & g, dry weight & \\
\hline Control (Soil) & $75 \pm 7.07$ & $170 \pm 0.00$ & $13.94 \pm 1.09$ & $2.98 \pm 0.71$ & 2 \\
\hline Growing medium 0 & $65 \pm 7.07$ & $225 \pm 35.36$ & $17.68 \pm 1.68$ & $3.14 \pm 0.38$ & 2 \\
\hline Growing medium 1 & $77 \pm 20.82$ & $250 \pm 50.00$ & $13.99 \pm 2.93$ & $2.21 \pm 0.56$ & 3 \\
\hline Growing medium 2 & $70 \pm 12.25$ & $342 \pm 54.95$ & $17.27 \pm 5.18$ & $3.09 \pm 0.91$ & 5 \\
\hline Growing medium 3 & $50 \pm 8.16$ & $290 \pm 80.42$ & $11.64 \pm 3.31$ & $1.74 \pm 0.80$ & 4 \\
\hline
\end{tabular}

Table 8 Properties of the investigated growing media after completion of the pot experiment

\begin{tabular}{lcllllll}
\hline Parameters & $\mathrm{pH}$ & Moisture content (MC) & Organic matter $(\mathrm{OM})$ & $\begin{array}{l}\text { Total organic } \\
\text { carbon (TOC) }\end{array}$ & Total nitrogen $(\mathrm{TN})$ & $\mathrm{P}_{2} \mathrm{O}_{5}$ & $\mathrm{C} / \mathrm{N}$ \\
\hline Units & - & $\%$ & $\%$ & $\%$ & $\%$ & $\mathrm{mg} \mathrm{g}^{-1}$ & - \\
Control (Soil) & 6.82 & $0.43 \pm 0.36$ & $3.98 \pm 0.09$ & $2.39 \pm 0.14$ & $0.13 \pm 0.01$ & $0.32 \pm 0.02$ & 18 \\
Growing medium 0 & 7.83 & $0.22 \pm 0.08$ & $5.67 \pm 0.37$ & $3.56 \pm 0.19$ & $0.21 \pm 0.01$ & $0.59 \pm 0.03$ & 17 \\
Growing medium 1 & 8.08 & $0.21 \pm 0.11$ & $5.54 \pm 0.17$ & $3.53 \pm 0.11$ & $0.20 \pm 0.02$ & $0.74 \pm 0.01$ & 18 \\
Growing medium 2 & 8.09 & $0.41 \pm 0.35$ & $6.06 \pm 0.29$ & $4.06 \pm 0.11$ & $0.21 \pm 0.01$ & $0.66 \pm 0.08$ & 19 \\
Growing medium 3 & 8.06 & $0.58 \pm 0.40$ & $5.57 \pm 0.32$ & $3.99 \pm 0.31$ & $0.20 \pm 0.01$ & $0.56 \pm 0.03$ & 20 \\
\hline
\end{tabular}

implementation of some provisions of the Act on fertilizers and fertilization, the chromium content should not exceed $100 \mathrm{mg} \mathrm{kg}^{-1}$ dry matter, cadmium $<5 \mathrm{mg} \mathrm{kg}^{-1}$ dry matter, nickel $<60 \mathrm{mg} \mathrm{kg}^{-1}$ dry matter, lead $<140 \mathrm{mg} \mathrm{kg}^{-1}$ dry matter [45]. The contents of none of these elements in the tested materials were exceeded [45].

\section{Conclusions}

Fish pond sediments from organic fish farming can be managed through composting with selected waste materials such as wet grass and wheat straw. The obtained compost from fish pond sediments demonstrated rather low contents of organic matter and organic carbon as compared to typical composts. This is mostly due to the higher content of mineral matter (i.e. sand). Therefore, the compost from organic fish pond sediments should be amended with materials that could increase the organic matter content and organic carbon, and allow for retention of water and nutrients. However, when amended with woodchips derived biochar and cardboard waste the compost from organic fish pond sediments demonstrated higher contents of organic matter and organic carbon. Fish pond sediments and their potentials for soil fertilization are poorly described in the literature. Therefore, it was difficult to find other studies on composting of organic fish pond sediments and fertilizing potential to make the comparison and contribute to discussion. Further research is needed to understand how various factors such as type of fish, breeding system, feed, seasonality, management of pond, etc. affect the composition of fish pond sediments. In addition, microbiological safety of fish pond sediments should be also addressed. 


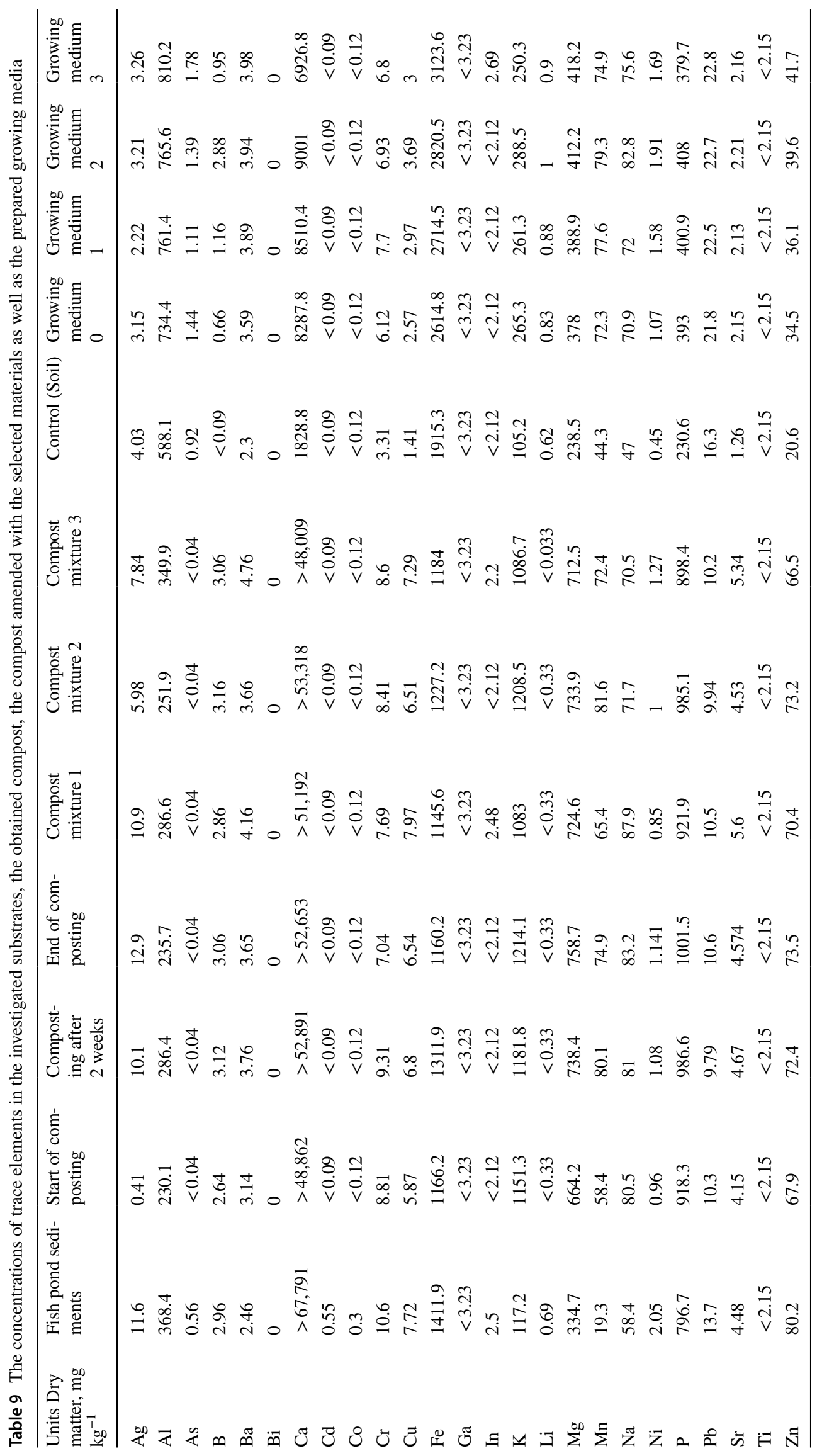


Acknowledgements This work was performed within the project on "Pathways to phase-out content from organic agriculture in Europe (Organic PLUS)" (2018-2022). This project has received funding from the European Union's Horizon 2020 research and innovation programme under Grant agreement No [774340].

Open Access This article is licensed under a Creative Commons Attribution 4.0 International License, which permits use, sharing, adaptation, distribution and reproduction in any medium or format, as long as you give appropriate credit to the original author(s) and the source, provide a link to the Creative Commons licence, and indicate if changes were made. The images or other third party material in this article are included in the article's Creative Commons licence, unless indicated otherwise in a credit line to the material. If material is not included in the article's Creative Commons licence and your intended use is not permitted by statutory regulation or exceeds the permitted use, you will need to obtain permission directly from the copyright holder. To view a copy of this licence, visit http://creativecommons.org/licenses/by/4.0/.

\section{References}

1. EU Organic Aquaculture, 2018. European Market Observatory for Fisheries and Aquaculture Products (EUFOMA), https://www. eumofa.eu/documents/20178/132648/EN_The+EU+fish+marke t+2018.pdf (2018). Accessed 29 April 2013

2. Rahman, M.M., Yakupitiyage, A.: Use of fish pond sediment for sustainable aquaculture-agriculture farming. Int. J. Sustain. Dev. Plan. 2, 192-202 (2006)

3. Statistic Poland, https://stat.gov.pl/obszary-tematyczne/rolni ctwo-lesnictwo/rybolowstwo/polowy-ryb-morskich-i-slodkowodn ych,1,1.html (2017). Accessed 25 March 2019

4. Report 9/2010 Nofima, 2010. Utilization of sludge from recirculation aquaculture systems. https://www.nofima.no/filearchive/ Rapport\%2009-2010.pdf (2010). Accessed 2 March 2010

5. Barszczewski, J., Kaca, E., Wojda, R.: The environmental conditions and production results in organic and conventional system of carp breeding. J. Res. Appl. Agric. Eng. 55(3), 14 (2010)

6. EU Organic Aquaculture, 2017. European Market Observatory for Fisheries and Aquaculture Products (EUFOMA), https://www. eumofa.eu/documents/20178/84590/Study+report_organic+aquac ulture.pdf (2017). Accessed 1 May 2017

7. Van Rijn, J.: Waste treatment in recirculating aquaculture systems. Aquacult. Eng. 53, 49-56 (2013)

8. Madeyski, M., Tarnowski, M.: Ocena stanu ekologicznego osadów dennych wybranych małych zbiorników wodnych. Polska Akademia Nauk, Oddział w Krakowie 4, 107-116 (2006)

9. Bosman, R.H., Verdegem, M.C.J.: Sustainable aquaculture in ponds: Principles, practices and limits. Livest. Sci. 139, 58-68 (2011)

10. Boyd, C.E., Massaut, L.: Risk associated with the use of chemicals in pond aquaculture. Aquacult. Eng. 4, 113-132 (1999)

11. Dróżdż, D., Malińska, K., Mazurkiewicz, J., Kacprzak, M., Mrowiec, M., Szczypiór, A., Postawa, P., Stachowiak, T.: Fish pond sediments from aquaculture production-current practices and potentials for nutrient recovery. Int. Agrophys. 34(1), 33-41 (2020). https://doi.org/10.31545/intagr/116394

12. Kouba, A., Lunda, R., Hlaváč, D., Kuklina, I., Hamáčková, J., Randák, T., Kozák, P., Koubová, A., Buřič, M.: Vermicomposting of sludge from recirculating aquaculture system using Eisenia andrei: Technological feasibility and quality assessment of endproducts. J. Clean. Prod. 177, 665-673 (2018)
13. Maj, K., Koszelnik, P.: Metody zagospodarowania osadów dennych. Czasopismo Inżynierii Lądowej, Środowiska I Architektury 63, 157-169 (2016)

14. Eymontt, A., Wierzbicki, K., Brogowski, Z., Burzyńska, I., Rossa, L.: Nowa technologia wydobywania osadów dennych z rowów na stawach rybnych i ich zastosowanie w rolnictwie. Komunikaty Rybackie 2(157), 7-13 (2017)

15. Haque, M.M., Belton, B., Alam, M.M., Ahmed, A.G., Alam, M.R.: Reuse of fish pond sediments as fertilizer for fodder grass production in Bangladesh: Potential for sustainable intensification and improved nutrition. Agric. Ecosyst. Environ. 216, 226-236 (2016)

16. Zhang, L., Sun, X.: Addition of fish pond sediment and rock phosphate enhances the composting of green waste. Biores. Technol. 233, 116-126 (2017)

17. Zhang, J., Chen, G., Sun, H., Zhou, S., Zou, G.: Straw biochar hastens organic matter degradation and products nutrient-rich kompost. Biores. Technol. 200, 876-883 (2016)

18. Mizanur, R., Yakupitiyage, A., Ranamukhaarachchi, S.L.: Agricultural use of fishpond sediment for environmental amelioration. Thammasat Int. J. Sci. Technol. 9(4), 1-10 (2004)

19. Del'Duca, A., Cesar, C.E., Abreu, P.C.: Bacterial community of pond's water, sediment and in the guts of tilapia (Oreochromis niloticus) juveniles characterized by fluorescent in situ hybridization technique. Aquacult. Res. (2013). https://doi.org/10.1111/ are. 12218

20. Randolph, P., Bansode, R.R., Hassan, O.A., Rehrah, D.J., Ravella, R., Reddy, M.R., Watts, D.W., Novak, J.M., Ahmedna, M.: Effect of biochars produced from solid organic municipal waste on soil quality parameters. J. Environ. Manag. 192, 271-280 (2017)

21. Czekała, W., Malińska, K., Caceres, R., Janczak, D., Dach, J., Lewicki, A.: Co-composting of poultry manure mixtures amended with biochar-The effect of biochar on temperature and C-CO emission. Biores. Technol. 200, 921-927 (2016)

22. Francou, C., Linères, M., Derenne, S., Le Villio-Poitrenaud, M., Houot, S.: Influence of green waste, biowaste and paper-cardboard initial ratios on organic matter transformations during composting. Biores. Technol. 99(18), 8926-8934 (2008)

23. Soil categories. https://www.susza.iung.pulawy.pl/kategorie-glebo we/. Accessed 1 August 2019

24. Juda-Rezler, K., Manczarski, P.: Zagrożenia związane z zanieczyszczeniem powietrza atmosferycznego i gospodarką odpadami komunalnymi. Nauka 4, 97-106 (2010)

25. Białobrzewski, I., Miks-Krajnik, M., Dach, J., Markowski, M., Czekała, W., Głuchowska, K.: Model of the sewage sludge-straw composting process integrating different heat generation capacities of mesophilic and thermophilic microorganisms. Waste Manag. 43, 72-83 (2015)

26. Chowdhury, M.A., Neergaard, A., Jensen, L.S.: Potential of aeration flow rate and bio-char addition to reduce greenhouse gas and ammonia emissions during manure composting. Chemosphere 97, 16-25 (2014)

27. Sołowiej, P.: Koncepcja budowy bioreaktora do kompostowania biomasy-stanowisko badawcze. Inżynieria rolnicza 11(109), 227-231 (2008)

28. Institute of Soil Science and Plant Cultivation State Research Institute (IUNG), Agricultural Drought Monitoring System (ADMS), https://www.susza.iung.pulawy.pl/kategorie-glebo we/ (2012). Accessed 8 April 2019

29. Rozporządzenie Rady Ministrów z dnia 5 czerwca 2018 w sprawie przyjęcia „Programu działań mających na celu zmniejszenie zanieczyszczenia wód azotanami pochodzącymi ze źródeł rolniczych oraz zapobieganie dalszemu zanieczyszczeniu". https://prawo.sejm.gov.pl/isap.nsf/download.xsp/WDU20 180001339/O/D20181339.pdf (2018). Accessed 12 July 2018 
30. Ociepa, E., Ociepa-Kubicka, A., Okoniewska, E., Lach, J.: Immobilizacja cynku i kadmu w glebach w wyniku stosowania substratów odpadowych. Ann. Set Environ. Protect. 15, 1772-1786 (2013)

31. Latifi, N., Marto, A., Eisazadeh, A.: Physicochemical behavior of tropical laterite soil stabilized with non-traditional additive. Acta Geotech. 11(2), 433-443 (2016)

32. PN-EN ISO 6878:2006 Jakość wody. Oznaczanie fosforu. Metoda spektrofotometryczna z molibdenianem amonu (2006)

33. Jarvie, D.M.: TR: Source and migration processes and evaluation techniques. In: Jarvie D.M., Total Organic (TOC) Analysis: Chapter 11: Geochemical Methods and Exploration, pp. 113118. American Association of Petroleum Engineers (AAPG), Texas (1991)

34. Mitelut, A.C., Popa, M.E.: Seed germination bioassay for toxicity evolution of different composting biodegradable materials. Roman. Biotechnol. Lett. 16(1), 121 (2011)

35. Radziemska, M., Vaverková, M.D., Adamcová, D., Brtnický, M., Mazur, Z.: Valorization of fish waste compost as a fertilizer for agriculture use. Waste Biomass Valor. 10(9), 1-9 (2018)

36. Rondon, M.A., Lehmann, J., Ramirez, J., Hurtado, M.: Biological nitrogen fixation by common beans (Phaseolus vulgaris L.) increases with biochar additions. Biol Fertil Soils 43, 699-708 (2007)

37. Vidal-Valverde, C., Frias, J., Sierra, I., Blazquez, I., Lambein, F., Kuo, Y.H.: New functional legume foods by germination: effect on the nutritive value of beans, lentils and peas. Eur. Food Res. Technol. 215, 472-477 (2002)

38. Karczewska, A., Kabała, C.: Metodyka analiz laboratoryjnych gleb i roślin-Oznaczanie przyswajalnych from fosforu, potasu i magnezu w glebie, 28-34. Uniwersytet Przyrodniczy we Wrocławiu, Instytut Nauk o Glebie i Ochrona Środowiska, Zakład Ochrony Środowiska, Wrocław (2008)

39. Huang, G.F., Wong, J.W.C., Wu, Q.T., Nagar, B.B.: Effect of $\mathrm{C} / \mathrm{N}$ on composting of pig manure with sawdust. Waste Manag. 24(8), 805-813 (2004)

40. Jimenez, E.I., Perez-Garcia, V.: Determination of maturity indices for city refuge composts. Agric. Ecosyst. Environ. 38(4), 331-343 (1992)

41. Piotrowska-Cyplik, A., Chrzanowski, Ł., Cyplik, P., Dach, J., Olejnik, A., Staninska, J., Czarny, J., Lewicki, A., Marecik, R., Powierska-Czarny, J.: Composting of oiled bleaching earth: fatty acids degradation, phytotoxicity and mutagenicity changes. Int. Biodeterior. Biodegradation 78, 49-57 (2013)

42. Gondek, K., Filipek-Mazur, B.: Agrochemiczna ocena wartości nawozowej kompostów różnego pochodzenia. Acta Agrophys. 5(2), 271-282 (2005)

43. Tanmoy, K., Bhattacharyya, P., Paul, R.K., Das, T., Saha, S.K.: Evaluation of composts from agricultural wastes with fish pond sediment as bulking agent to improve compost quality. Clean: Soil, Air, Water 41(7), 711-723 (2013). https://doi.org/10.1002/ clen.201200142

44. Schulz, H., Dunst, G., Glaser, B.: Positive effects of composted biochar on plant growth and soil fertility. Agron. Sustain. Dev. 33(4), 817-827 (2013)

45. Rozporządzenie Ministra Rolnictwa i Rozwoju Wsi z dnia 18 czerwca 2008 r. w sprawie wykonania niektórych przepisów ustawy o nawozach i nawożeniu. https://prawo.sejm.gov.pl/isap.nsf/DocDe tails.xsp?id=WDU20081190765 (2008). Accessed 22 July 2008

Publisher's Note Springer Nature remains neutral with regard to jurisdictional claims in published maps and institutional affiliations.

\section{Affiliations}

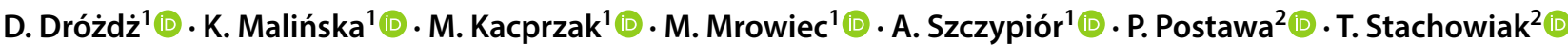

1 Department of Environmental Engineering, Częstochowa University of Technology, Brzeźnicka 60A, 42-200 Częstochowa, Poland
2 Department of Technology and Automation, Częstochowa University of Technology, al. Armii Krajowej 21, 42-200 Częstochowa, Poland 